\title{
DEVELOPMENT AND USE OF GIS DATABASE FOR TASKS OF NORMATIVE MONETARY EVALUATION OF LAND OF SETTLEMENTS
}

P.I. TROFYMENKO, Doctor of Sciences in Agriculture, Associate Professor of Geoinformatics

Email: trofimenkopetr@ukr.net

Taras Shevchenko National University of Kyiv

A.M. TRETYAK, Doctor of Economics, Professor, Corresponding Member of NAAS, Department of Land Resources Management and Land Cadastre,

Email:tretyak2@ukr.net

Bila Tserkva National Agrarian University

Yu.V. BEZGODKOVA, student

Email:yuliabezgod@gmail.com

N.V. TROFIMENKO, Candidate of Economic Sciences, Assistant

Email: trofimenko.nadia.v@gmail.com

V.I. ZATSERKOVNIY, doctor of technical sciences, professor

Department of Geoinformatics

Email: vitalii.zatserkovnyi@gmail.com

Taras Shevchenko National University of Kyiv

Abstract.The paper presents the results of research on the development of a GIS database for the tasks of normative monetary valuation of lands of settlements and highlights the applied aspects of its use on the example of Lychanka village, Dmytriv territorial community, Bucha district, Kyiv region.

An algorithm for developing a GIS database for normative monetary valuation of settlement lands is presented. The presented estimation algorithm allows to carry out 
with high accuracy normative monetary estimation of settlements, to carry out its automated updating on a certain date, to receive necessary information on request, to carry out analytical operations and construction of specialized estimation maps.

The development of the GIS database involved the implementation of two stages. At the first stage of formation of the initial land assessment base, the attribute table included data from the Public Cadastral Map of Ukraine on land plots within the settlement by the following items: cadastral number of land plot, area, form of ownership, purpose and functional use of land plot, the number of the cadastral zone in which each land is located, the number of the land assessment area of the settlement, the value of the base value of land, the value of the zonal coefficient $(\mathrm{Km} 2)$, the coefficient characterizing the functional purpose of the land (Kf), information on the location (street name). The second stage involved the calculation of the value of the normative monetary valuation of each of the 1279 land plots and was performed using the built-in Arc Map function "Calculation of numerical values".

After the development of the GIS database, the testing stage of the developed land assessment database was performed, which involved the use of various query execution, geospatial analysis, the use of buffering functions, topological overlay (intersection).

As a result of the analysis, the following maps were constructed: "Influence of local factors on the distance of land from the center of the settlement", "Influence of local factors on the distance of land from highways", "Influence of local factors on the environmental situation", "Influence of local factors on security electricity", "Influence of local factors on the distance from paved roads", "Influence of local factors on the provision of centralized water supply", "Influence of local factors on the provision of centralized sewerage", "Influence of local factors on the provision of centralized gas supply", "Map plots according to the results of normative monetary assessment" , "Map of the establishment of buffer zones by the value of local coefficients" , "Map of coastal protection strips around water bodies with the allocation of zones of their intersection with land". 
Due to the application of special functions of geospatial analysis available in the GIS environment, examples of development of highly informative cartographic materials in the form of special pricing zoning of the territory of the settlement are shown. The expediency of the application of the GIS database for the tasks of monitoring the quality of land, compliance with their legal regime and the possibility of monitoring the implementation of fiscal obligations by landowners and users.

Key words: normative monetary valuation, GIS database, geospatial analysis, buffering, land valuation zoning, maps.

Topicality. It is well known that the land fund of any state is a strategically important component of its successful operation. In Ukraine, 17.06. 2021, the Law of Ukraine "On Amendments to Certain Legislative Acts of Ukraine on Land Use Planning" [10] came into force, which provides for a combination of land management and urban planning documentation in the form of a "Comprehensive Spatial Development Plan of the Territorial Community" and expanded the classification of restrictions. land use [4].

This, and the change of paradigm of land management and land use [15] determines the next stage of transformation of the land management system, the issue of land valuation is extremely important. Timely cash receipts in the form of taxes for the use of land in the budgets of the state, territorial communities and owners are evidence of proper fiscal policy and efficient use of land. That is why the timely conduct of regulatory monetary valuation is a significant achievement of the stable economic situation of local communities and the country as a whole.

In this regard, the issue of developing an automated system that would work stably and well-organized in order to calculate the monetary value of land within the settlements and the territory of territorial communities as a whole is quite relevant. The introduction of geographic information systems (GIS) primarily to automate the process of calculating the results of monetary valuation of land in settlements allows you to save manpower and quickly update previously received information. 
Analysis of recent research and publications. The urgency of integrating GIS into the land valuation procedure has become even more important in recent years due to the strong development and implementation of IT technologies. Gubar Yu. P. (2019), which highlights the need to use problem-oriented geographic information systems as an indispensable tool for the effective implementation of land relations [5], Palekha Yu.M. , Shipulin VD, Svinaryov AV (2015) substantiate the need for automation of cadastral works, unification of land management documentation in a single database [8].

Similarly, the importance of the use of GIS in real estate valuation is described in the articles by Taratula RB (2017) [12], Tretyaka AM, Panchuk O.Ya., Likhogruda MG (1999) [14], E. Butenko and A. Kononyuk (2019) [3] and many other authors.

In the work of Patichenko OM (2013) proved the feasibility of integrating the State Land and Urban Cadastre on the basis of a specialized geographic information system to ensure the exchange of information between urban GIS and LIS (land information system) normative monetary valuation of land to optimize the interaction of urban planning and land management [9].

Given the above, the tasks of digitalization of land valuation works are quite relevant, which is consistent with the modern concept of automation in land, urban cadastre and land management.

The purpose of the work is to improve the algorithm for developing a GIS database for normative monetary valuation of the settlement and the use of its results.

Materials and methods of research. The object of the study was the village of Lychanka, Dmytriv Territorial Community, Bucha District, Kyiv Region.

The research used materials of the normative monetary valuation of land plots (NVLP) as of 2007, including graphic materials of NVLP (in particular, soil boundaries) [13], information on cadastral division and land plots of Lychanka village - public cadastral map of Ukraine - more PCMU) [11]

The calculation of the monetary valuation of land was carried out in accordance with existing regulations and guidance materials $[5,7,10]$. 
An integral part of the normative monetary valuation of the settlement with the use of GIS is the creation of new and the use of existing cartographic materials. Binding, digitization of cartographic bases, formation of GIS database and geospatial analysis were performed using ArcGis 10.2 software.

The PCMU-based raster map base was linked to the WGS_1984_UTM_Zone_36N coordinate system and transformed from .jpeg to .tif. Data entry from the PCMU was carried out using a keyboard.

Research results and their discussion. Based on the original raster image of the village of Lychanka in the context of cadastral division by digitization, the main vector layer was created, with the identification of 1279 land plots within it (Fig. 1).

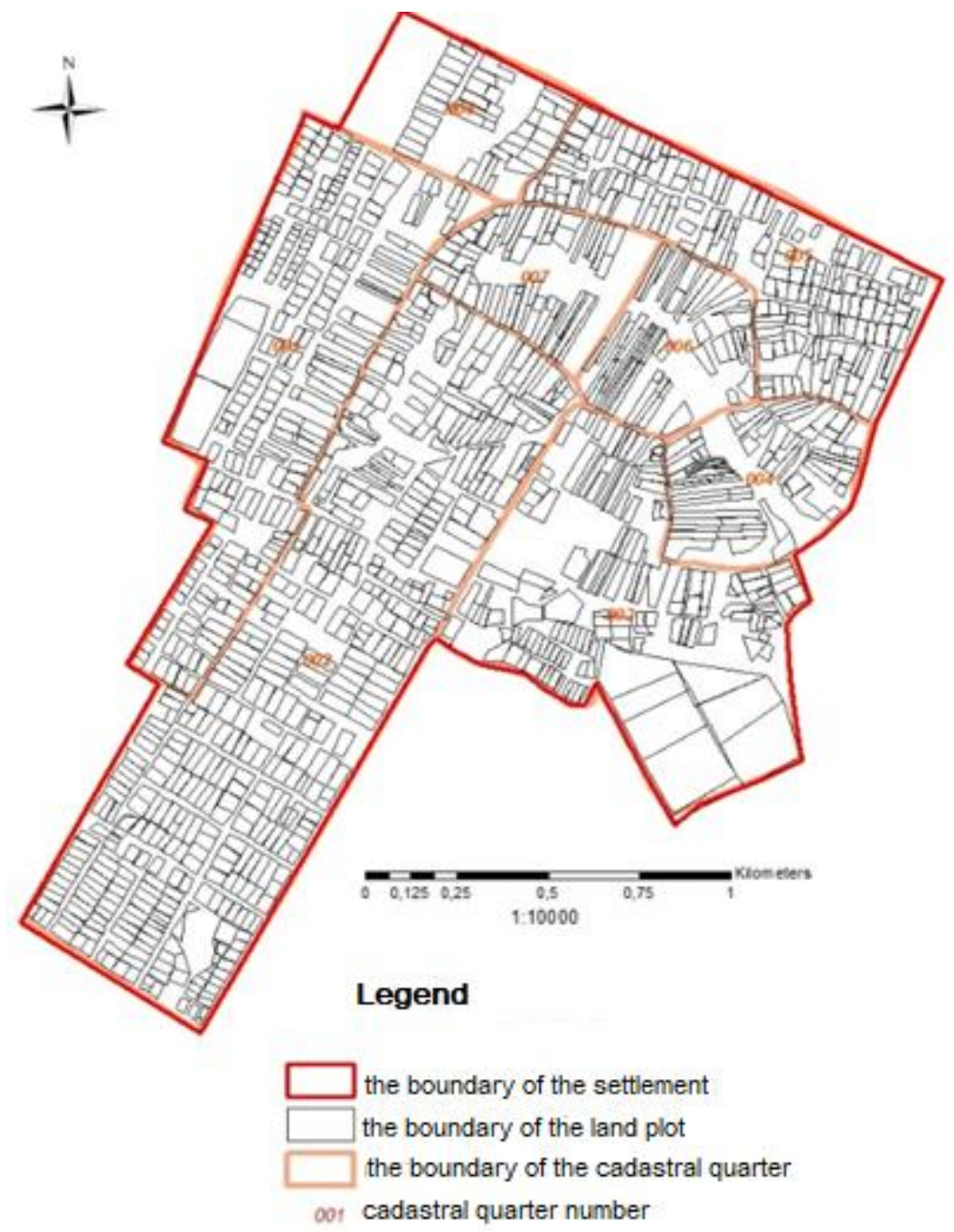

Fig. 1. Vector layer of cadastral division of the settlement 
Together, as a result of digitization of the source materials, 4 vector layers were obtained: cadastral division of the settlement (a), land valuation structuring (b), functional use (c), soil cover within the village of Lychanka (d) (Fig. 2).

In addition to vector graphic materials with spatial and coordinate data, an important component in creating a cadastre is semantic data. Descriptive data play an important supporting role and serve as an information basis for the identification of graphical objects, queries, calculations, analytical operations, mathematical modeling.

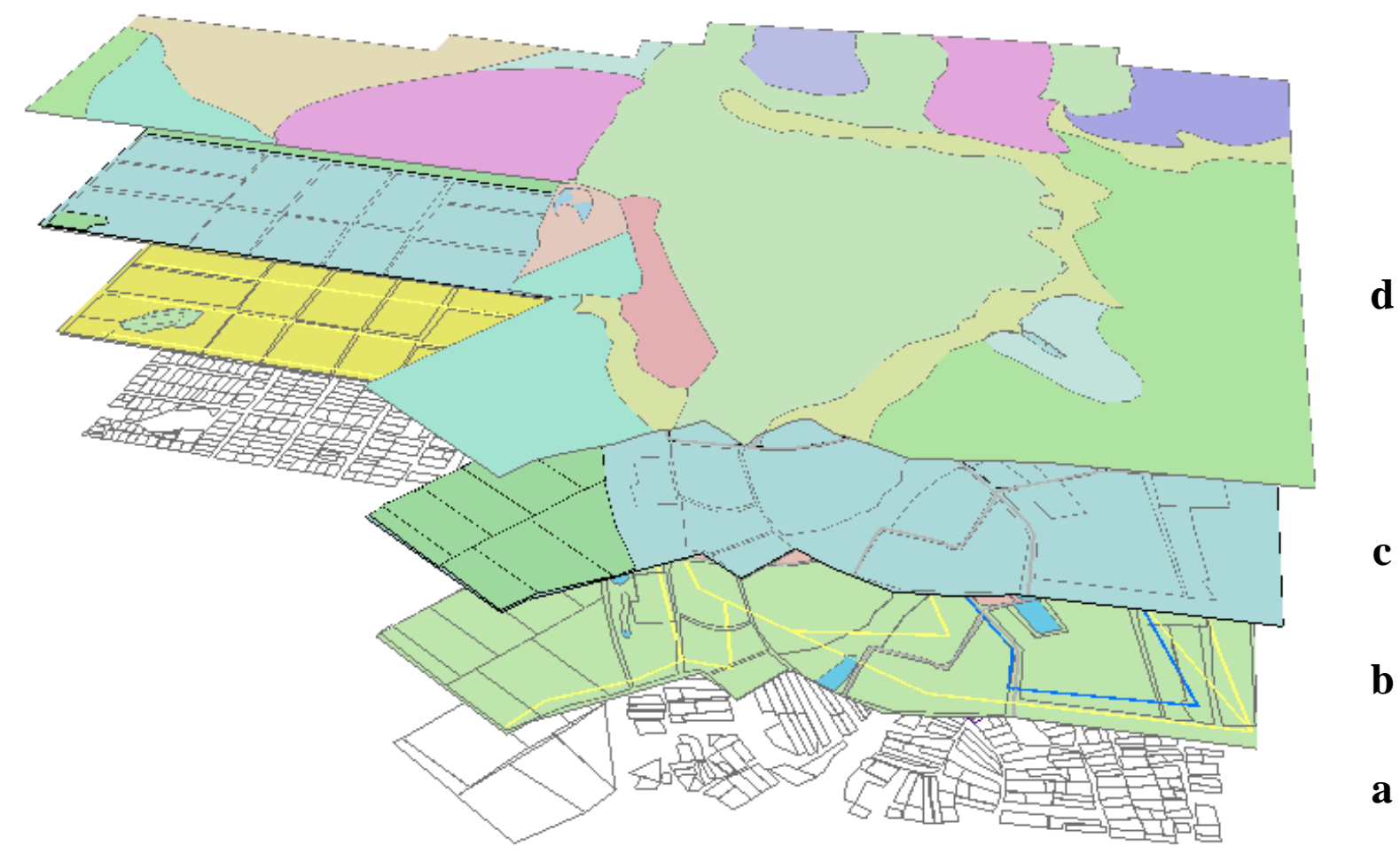

Fig. 2. Architecture of vector GIS layers on the territory of the village of

\section{Lichanka}

At the first stage of formation of the land assessment base, data from the State Land Cadastre on land plots within the settlement were entered into the attribute table, namely:

- cadastral number of the land plot;

- area, ha;

- ownership;

- purpose and functional use of the land plot. 
For land plots within the settlement, in addition to the purpose of the land plot, the following data was added to the database:

- number of the cadastral zone in which each land plot is located;

- number of the land assessment area of the settlement;

- the base value of land;

- the value of the zonal coefficient $(\mathrm{Km} 2)$

- coefficient that characterizes the functional purpose of the land plot (Kf);

- information on the location (street name).

A fragment of the database is shown in Figure 3.

\begin{tabular}{r|r|l|l|r|}
\hline OBJE & \multicolumn{1}{|c|}{ cad number } & \multicolumn{1}{c|}{ ownership } & S ha \\
\hline & 1 & $3222484601: 01: 002: 5179$ & Private property & 0,018 \\
\hline 2 & $3222484601: 01: 002: 5083$ & Private property & 0,08 \\
\hline 3 & $3222484601: 01: 002: 5028$ & Private property & 0,1459 \\
\hline & 4 & $3222484601: 01: 002: 5017$ & Private property & 0,1459 \\
\hline 5 & $3222484601: 01: 002: 0292$ & Private property & 0,11 \\
\hline & 3 & $3222484601: 01: 002: 5056$ & Private property & 0,1 \\
\hline 7 & $3222484601: 01: 002: 5087$ & Private property & 0,1072 \\
\hline & 8 & $3222484601: 01: 002: 5029$ & Private property & 0,08 \\
\hline & 9 & $3222484601: 01: 002: 5055$ & Private property & 0,1 \\
\hline 10 & $3222484601: 01: 002: 5012$ & Private property & 0,1 \\
\hline 11 & $3222484601: 01: 002: 0260$ & Private property & 0,149 \\
\hline 12 & $3222484601: 01: 002: 0281$ & Private property & 0,149 \\
\hline 13 & $3222484601: 01: 002: 5041$ & Private property & 0,149 \\
\hline 14 & $3222484601: 01: 002: 0189$ & Private property & 0,149 \\
\hline 15 & $3222484601: 01: 002: 0187$ & Private property & 0,149 \\
\hline 16 & $3222484601: 01: 002: 5030$ & Private property & 0,08 \\
\hline 17 & $3222484601: 01: 002: 5218$ & Private property & 0,06 \\
\hline 18 & $3222484601: 01: 002: 5162$ & Private property & 0,075 \\
\hline 19 & $3222484601: 01: 002: 5169$ & Private property & 0,1013 \\
\hline 20 & $3222484601: 01: 002: 5064$ & Private property & 0,1013 \\
\hline 21 & $3222484601: 01: 002: 5199$ & Private property & 0,0107 \\
\hline 22 & $3222484601: 01: 002: 5010$ & Private property & 0,1937 \\
\hline 23 & $3222484601: 01: 002: 5101$ & Private property & 0,097 \\
\hline 24 & $3222484601: 01: 002: 0110$ & Private property & 0,097 \\
\hline 25 & $3222484601: 01: 002: 0111$ & Private property & 0,097 \\
\hline 26 & $3222484601: 01: 002: 0136$ & Private property & 0,097 \\
\hline 27 & $3222484601: 01: 002: 0101$ & Private property & 0,097 \\
\hline & & &
\end{tabular}

03.07 For the construction and maintenance of trade buildings for the construction and $m$ 02.01 For the construction and maintenance of a dwelling house, outbuildings and struct 02.01 For the construction and maintenance of a dwelling house, outbuildings and struct 02.01 For the construction and maintenance of a dwelling house, outbuildings and struct 02.01 For the construction and maintenance of a dwelling house, outbuildings and struct 02.01 For the construction and maintenance of a dwelling house, outbuildings and struct 02.01 For the construction and maintenance of a dwelling house, outbuildings and struct 02.01 For the construction and maintenance of a dwelling house, outbuildings and struct 02.01 For the construction and maintenance of a dwelling house, outbuildings and struct 02.01 For the construction and maintenance of a dwelling house, outbuildings and struct 02.01 For the construction and maintenance of a dwelling house, outbuildings and struct 02.01 For the construction and maintenance of a dwelling house, outbuildings and struct 02.01 For the construction and maintenance of a dwelling house, outbuildings and struct 02.01 For the construction and maintenance of a dwelling house, outbuildings and struct 02.01 For the construction and maintenance of a dwelling house, outbuildings and struct 02.01 For the construction and maintenance of a dwelling house, outbuildings and struct 02.01 For the construction and maintenance of a dwelling house, outbuildings and struct 02.01 For the construction and maintenance of a dwelling house, outbuildings and struct 02.01 For the construction and maintenance of a dwelling house, outbuildings and struct 02.01 For the construction and maintenance of a dwelling house, outbuildings and struct 02.01 For the construction and maintenance of a dwelling house, outbuildings and struct 02.01 For the construction and maintenance of a dwelling house, outbuildings and struct 02.01 For the construction and maintenance of a dwelling house, outbuildings and struct 02.01 For the construction and maintenance of a dwelling house, outbuildings and struct 02.01 For the construction and maintenance of a dwelling house, outbuildings and struct 02.01 For the construction and maintenance of a dwelling house, outbuildings and struct 02.01 Для будівництва і обслуговування житлового будинку, господарських будіве

\section{Fig. 3. A fragment of the attribute table of the database}

The values of the normative monetary valuation of each land plot were calculated using the built-in calculation function.

As a result of these actions and the development of land valuation database, it became possible to conduct automated identification of any land and obtain available information, which as an example, structured by 12 indicators (Fig. 4). However, due to the expansion of the list of restrictions on land use that can be established by a comprehensive plan of spatial development of the territorial community, the general plan of the settlement, a detailed plan of the territory [4], these indicators need expanded. 


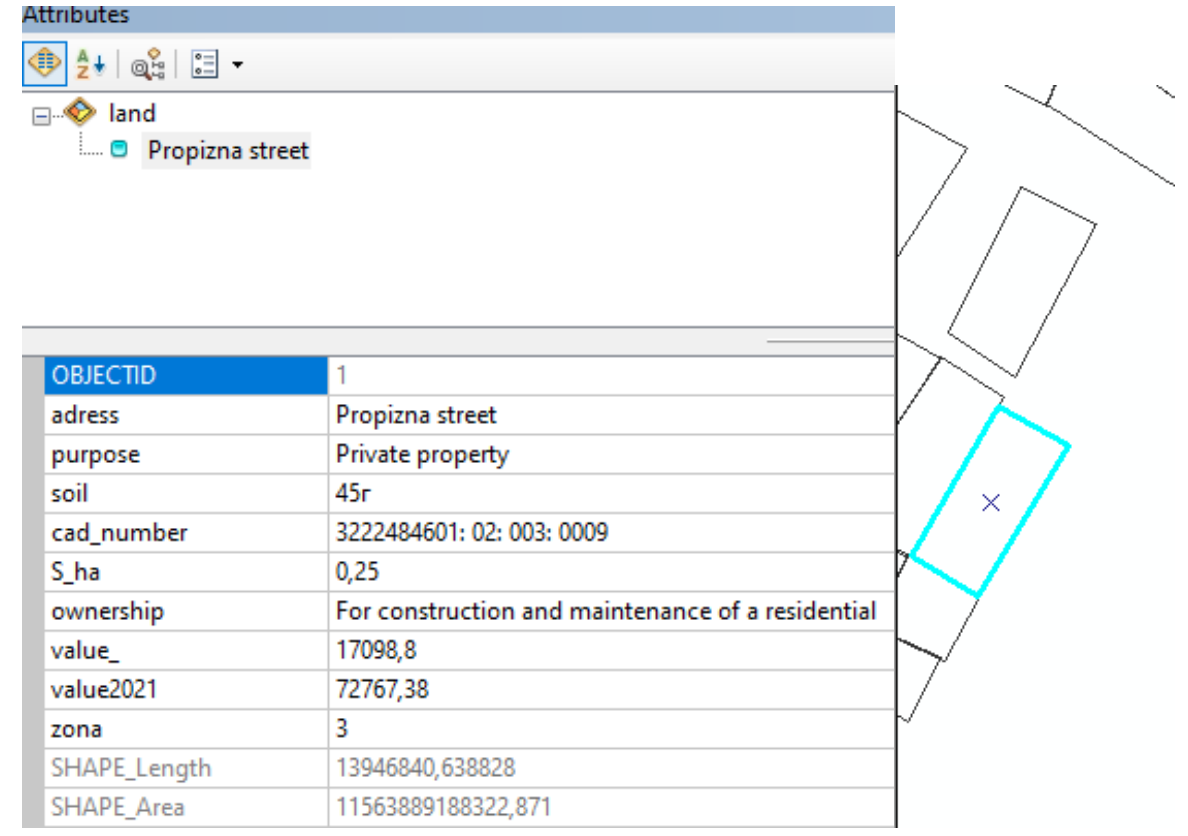

Fig. 4. Results of the information request on the land plot for construction and maintenance of a residential building, outbuildings and structures with cadastral number 3222484601: 02: 003: 0009

An important advantage of GIS is the ability to create complex queries, especially in a large amount of disparate data. In order to demonstrate the functionality of the developed base, a search was performed for the attributes of the availability of centralized sewerage and water supply on land plots (Fig. 5).
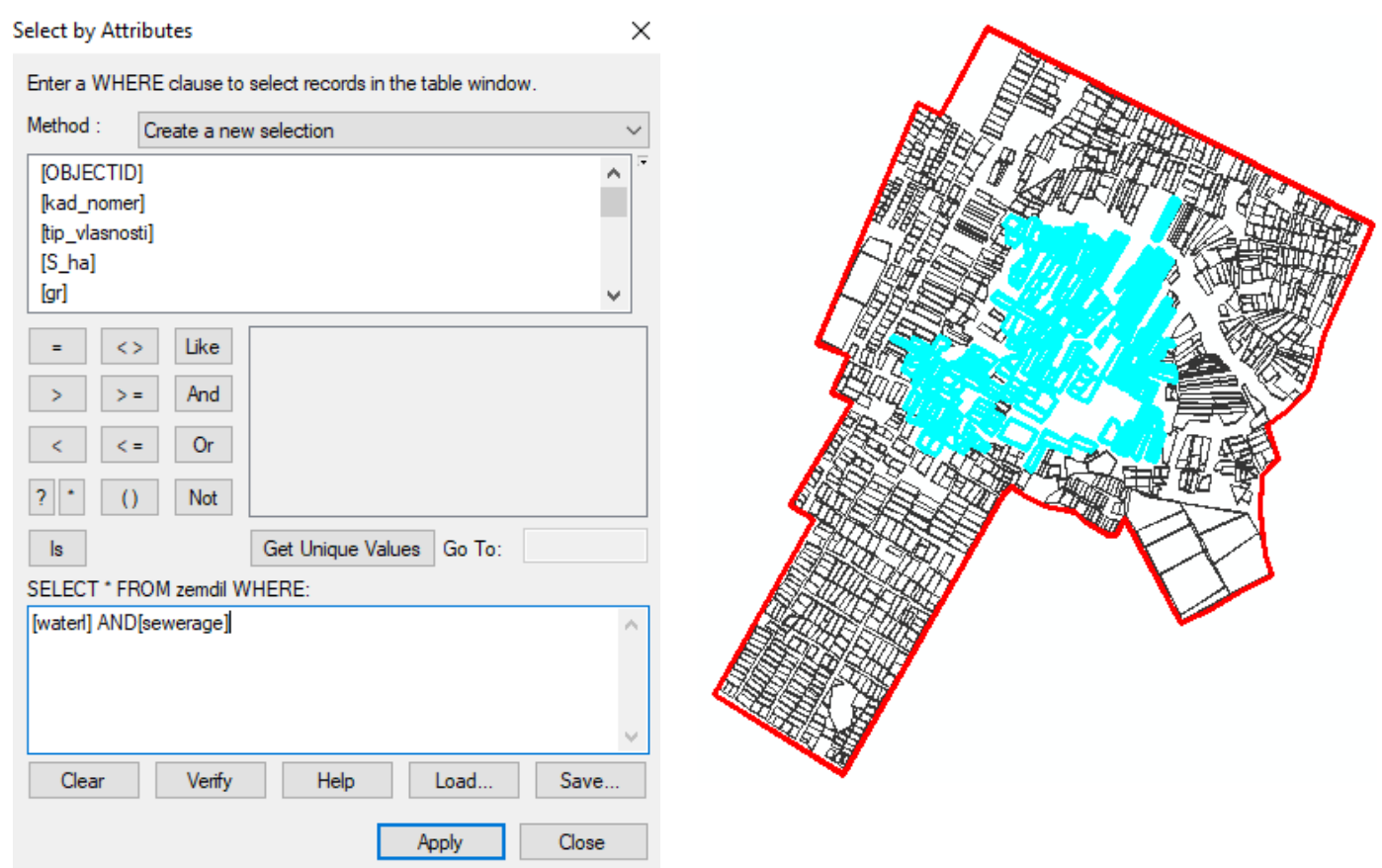

Fig. 5. The result of the query for the attributes of local factors (centralized 


\section{sewerage and water supply)}

Appropriate maps were created to visually display the influence of local factors in the automated mode (Fig. 6-13).
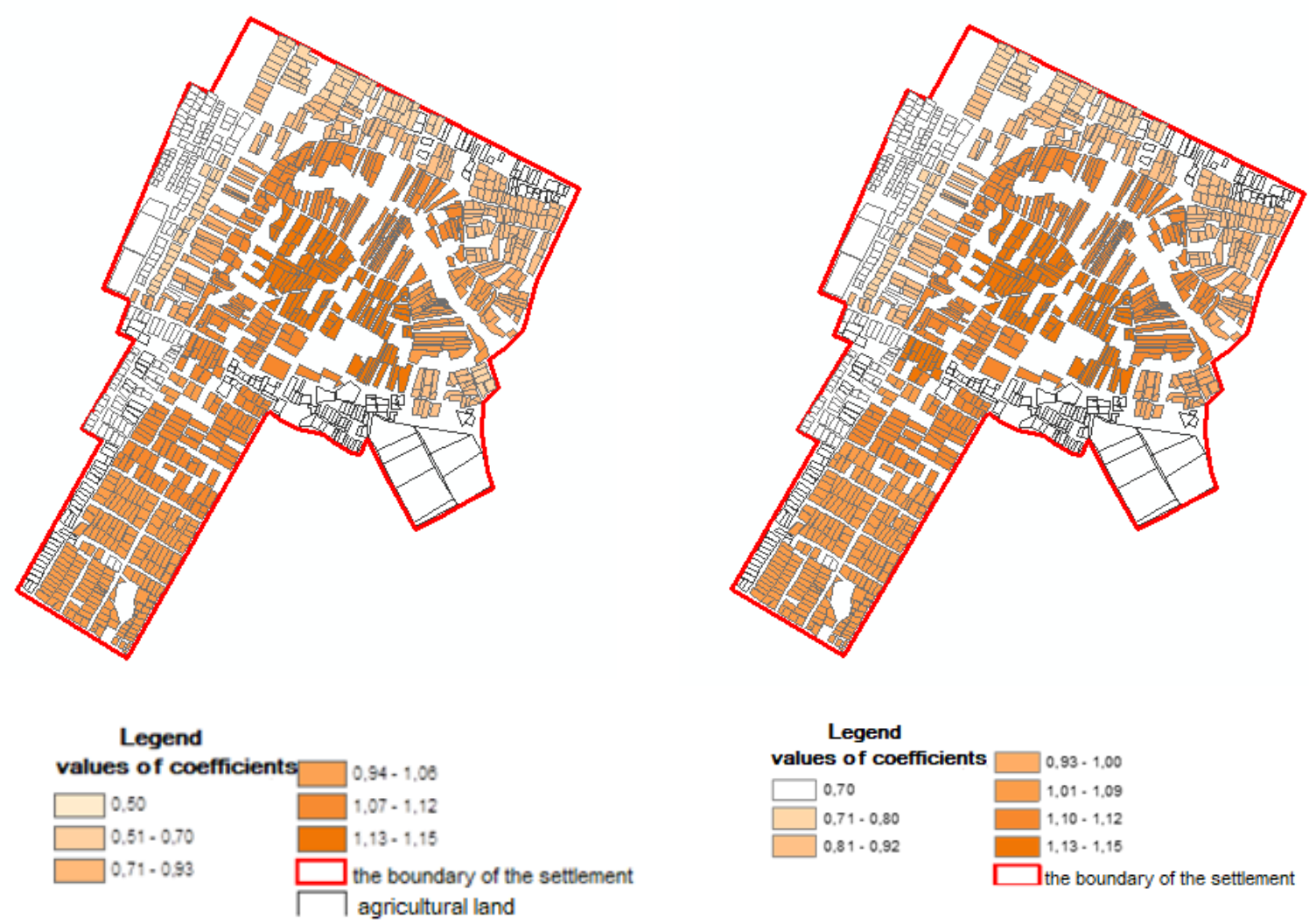

Fig. 6. Influence of local factors Fig. 7. Influence of local factors concerning the distance of the land concerning the distance of the land plot plot from the center of the settlement from the highways
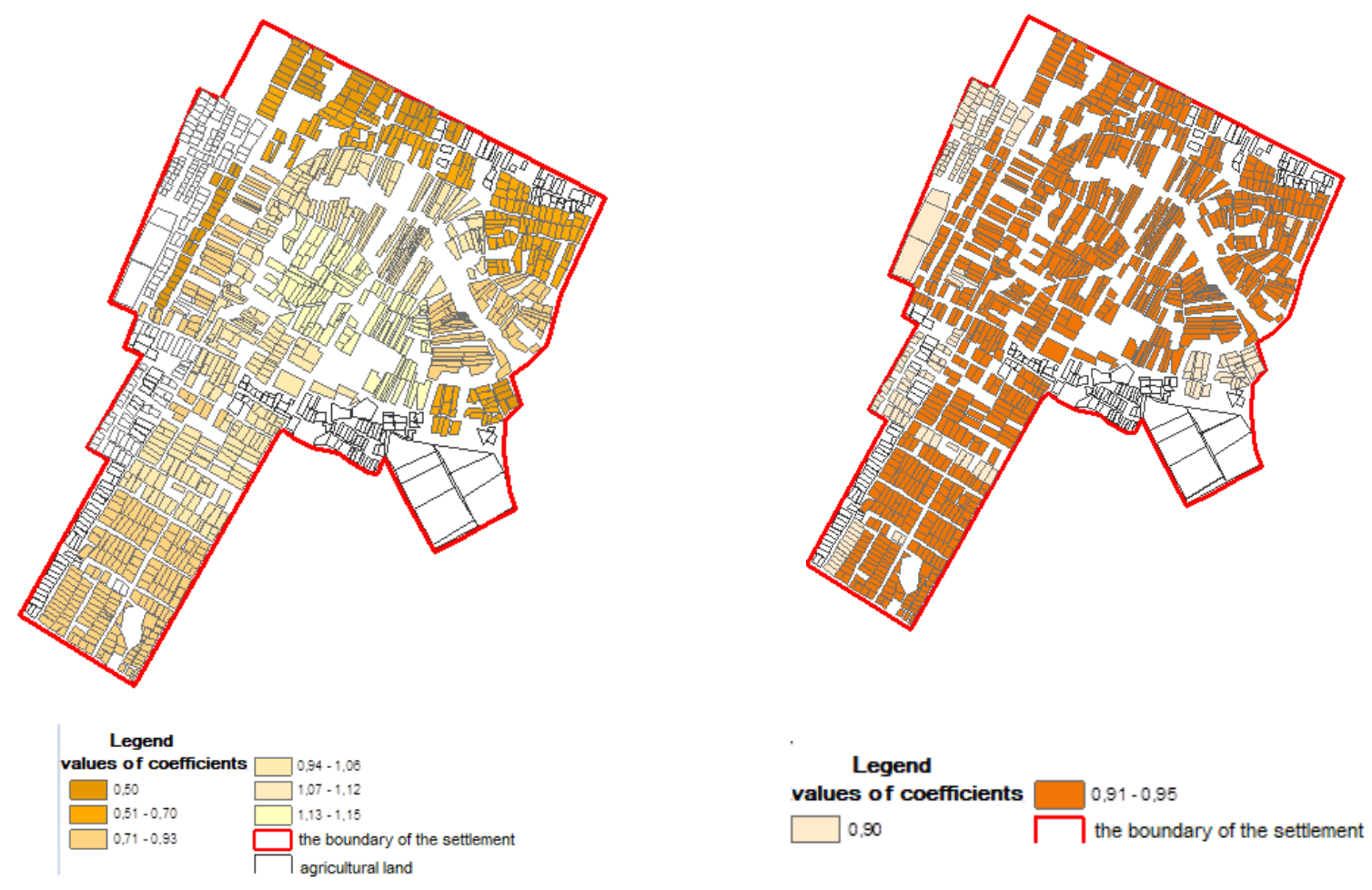
Fig. 8. Influence of local Fig. 9. Influence of local factors factorsconcerning the ecological concerning electricity supply situation

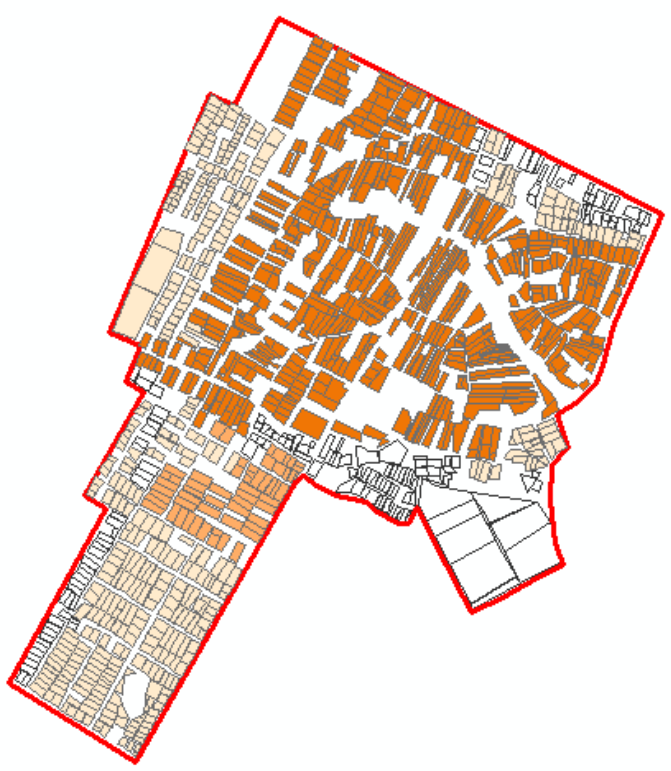

Legend

values of coefficients
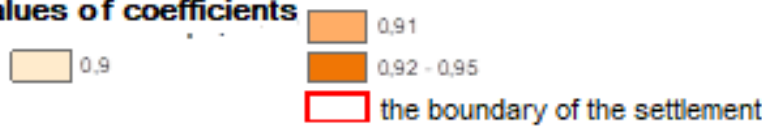

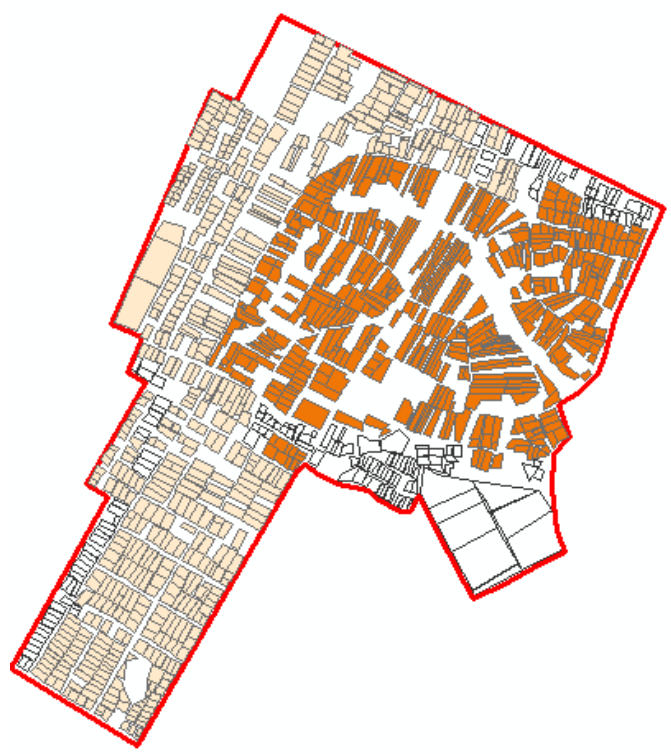

Legend

values of coefficients $\square \quad 0.93-0.95$

$\square 0.90-092 \quad \square$ the boundary of the settlement

Fig. 10. Influence of local Fig. 11. Influence of local factors factorsconcerning the distance from concerningproviding centralized water the paved road

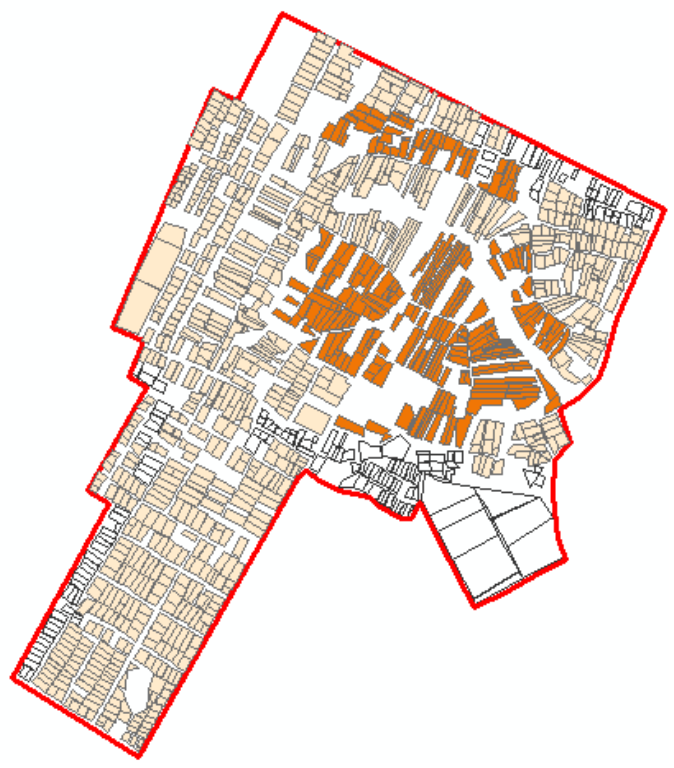
supply

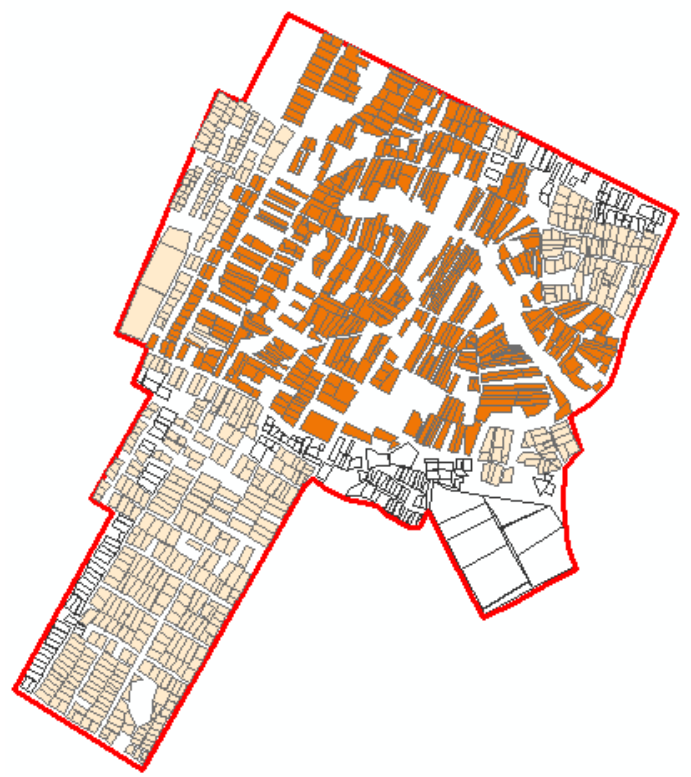



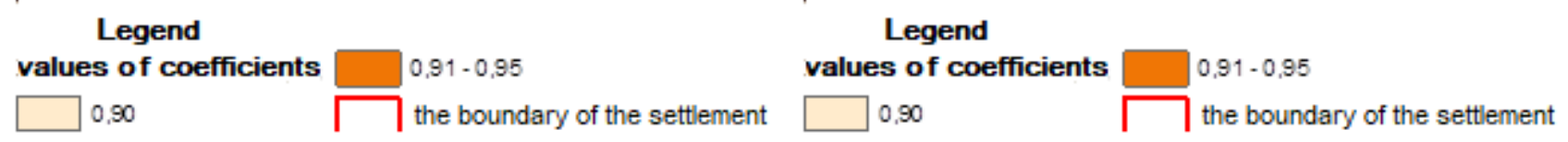

Fig. 12. Influence of local Fig. 13. Influence of local factorsconcerning the provision of factorsconcerning providing centralized sewerage centralized gas supply

The obtained maps sufficiently demonstrate all the technical components of the formation of the value of the normative monetary valuation of lands of the settlement and serve as a highly informative source for the governing bodies of the local community, potential investors, fiscal units and interested legal entities.

During the work, buffer zones were also established to determine the influence of local factors, such as: distance from the center, distance to roads of urban significance, distance to paved roads. An example of the use of buffer zones in this aspect is shown in Fig. 14.
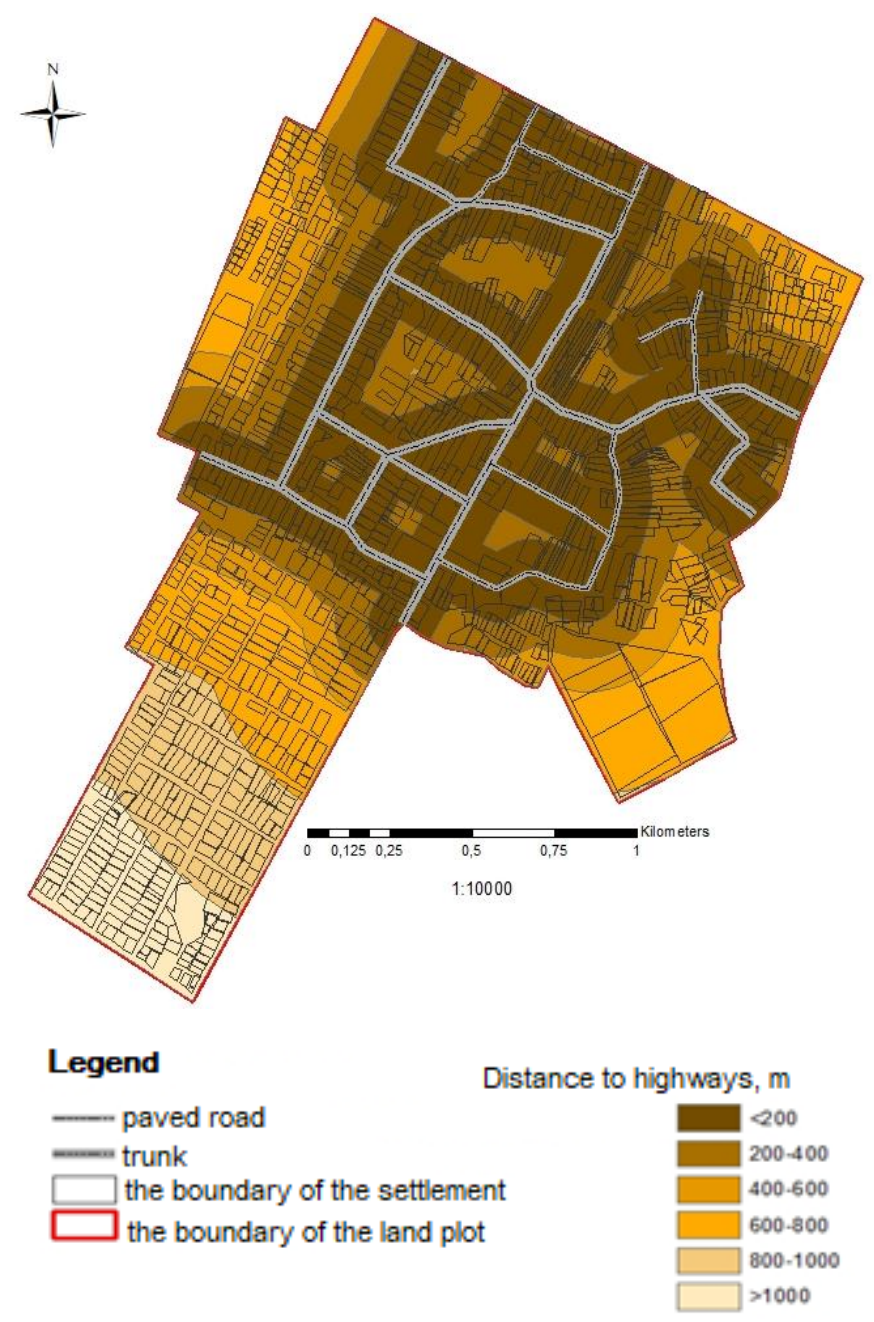

Fig. 14. Map of installation buffer zones by the value of local coefficients 
The farther the land is from the highways, the smaller the local coefficient it will have on this basis.

Therefore, with the help of analytical operations in GIS, it is convenient to calculate the normative monetary valuation, operational queries for attributes, verification of geospatial data, tools for constructing buffers, and so on.

Based on the entered data and the calculated normative monetary assessment, a map of the graphical display of the value of land plots within the settlement was created (Fig. 15).

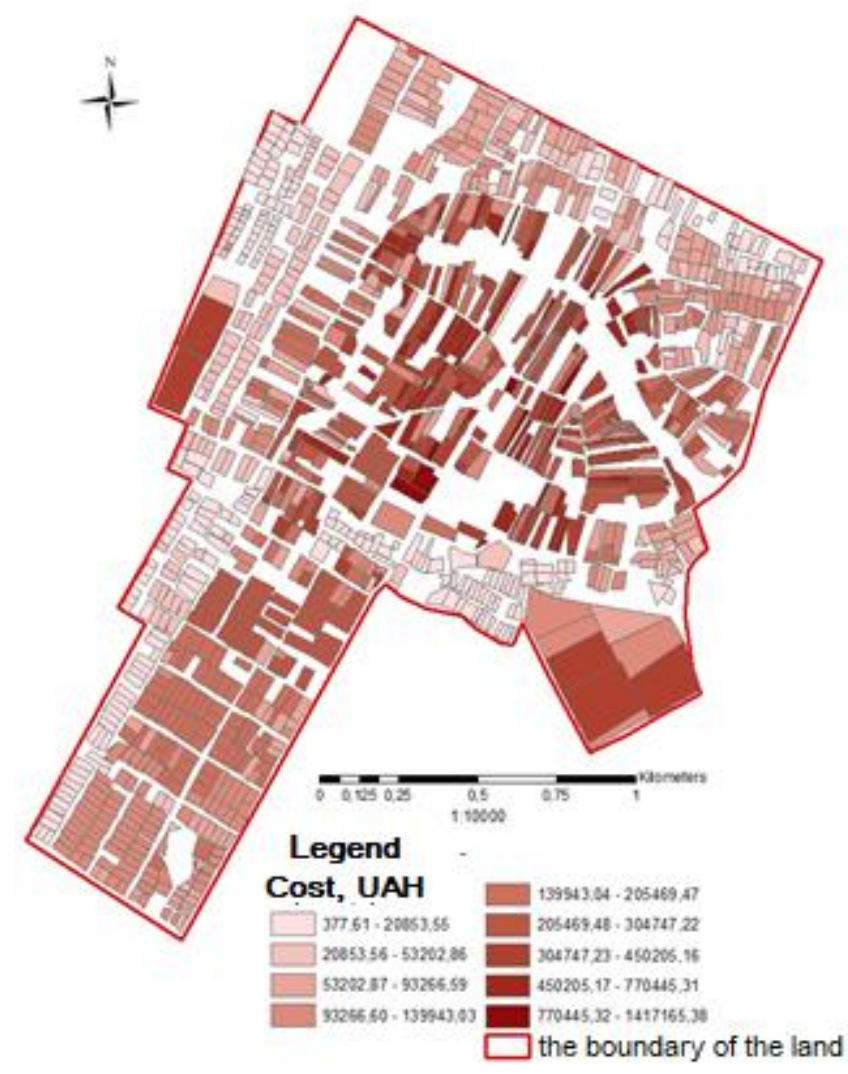

Fig. 15. Map of the value of land plots according to the results of normative monetary valuation

In accordance with the developed map, the maximum cost of land for housing and public buildings is concentrated in the central part of the village.

Similar to the maps developed above, the buffering functions used to represent the protective, coastal protection strips, as well as for a separate flood zone, which is an important factor in influencing the establishment of coefficients. 
With this use of the coastal protection zone, in accordance with current legislation, a buffer with a radius of $25 \mathrm{~m}$ was installed (Fig. 16).

With the help of GIS tools, land plots or their parts located within the coastal protection strips were identified, this operation was performed by analyzing their vector and layered construction ("overlay"),in particular the intersection function.

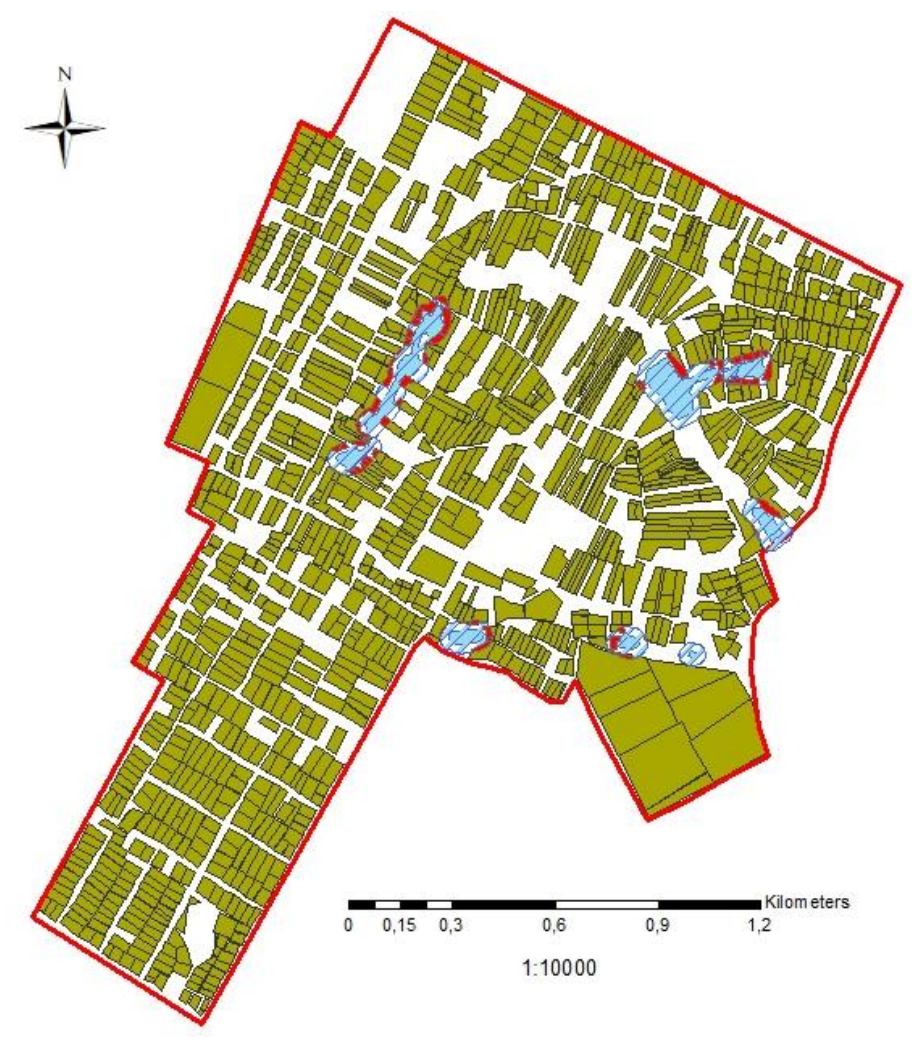

\section{Legend}

the boundary of the land plot

the boundary of the settlement

water fund object

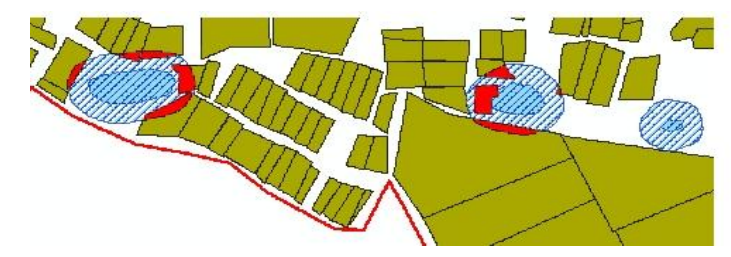

WV protective strip

intersection area

fragment of a map with areas of intersection

Fig. 16. Map of coastal protection strips around water bodies with allocation of zones of their intersection with land plots

The results of the geospatial analysis identified parts of land plots that are in the area of coastal protection strips around water bodies, which in this case indicates the necessary appropriateresponse of regulatory authorities is required. 
Thus, the function of automated localization of parts of land plots allows state geocadastre bodies and land management departments of territorial communities to carry out operational monitoring of lands with a special legal regime of use.

It is obvious that on certain plots of land there should be a regime for land use (restriction codes 05.01 and 05.02).

Conclusions and prospects. In Ukraine, 17.06. 2021, The Law of Ukraine "On Amendments to Certain Legislative Acts of Ukraine on Land Use Planning" is in force, as it provides a combination of land management and urban planning documentation in the form of a "Comprehensive Spatial Development Plan of the territorial community" and which expands the classification of land use restrictions and changes paradigms of land resources management and land use There is an urgent need to develop and use during the normative monetary valuation of land settlements geographic information systems that provide automation of results and their prompt updating.

The given estimation algorithm allows to carry out with high accuracy normative monetary estimation of settlements, to carry out automation of updating for a certain date, to support the necessary information for inquiry, to carry out analytical operations and construction of specialized estimation maps, providing performance of fiscal functions. The use of approaches and the versatility of the use of the obtained data during the development of the land assessment GIS database testify to the expediency of spreading such systems at the levels of territorial communities, and further on the lands of all communities. The use of data formats in the development, the relative ease of work and the ability to integrate this database with systems of other types of cadastres, create a conclusion about the prospect of disseminating the presented example of its practical implementation.

In addition, similarly developed databases in combination with virtually unlimited capabilities of different types of analysis will determine the most effective types of land use for individual regions of the state, which will ultimately help optimize the process of land management. 


\section{References}

1. Butenko Ye., Kononiuk A. (2019). Zastosuvannia HIS-tekhnolohii pry provedeni hroshovoi otsinky. [The use of GIS technologies in monetary valuation]. All-Ukrainian scientific-practical conference "Cartographic modeling and geographic information systems". 03-05.10.2019, Lviv, Ukraine: 87-89.

2. Hubar Yu.P. (2019). Zastosuvannia tekhnolohii HIS dlia masovoi otsinky zemel. [Application of GIS technology for land valuation]. All-Ukrainian scientific-practical conference "Cartographic modeling and geographic information systems". 03-05.10.2019, Lviv, Ukraine: 57-59.

3. Law of Ukraine "On Land Valuation" of 24.07.2021. Available at: https://zakon.rada.gov.ua/laws/show/1378-15\#Text

4. Resolution of the Cabinet of Ministers of Ukraine "Classification of restrictions in the use of land that can be established by a comprehensive plan of spatial development of the territorial community, the general plan of the settlement, a detailed plan of the territory" of June 23, 2021 No. 654. Available at: https://zakon.rada.gov.ua/laws/show/654-2021-\%D0\%BF\#Text

5. Order of the Ministry of Agricultural Policy and Food of Ukraine "On approval of the Procedure for normative monetary valuation of lands of settlements" of December 28, 2018.Available at: https://zakon.rada.gov.ua/laws/show/z1647$16 \#$ Text

6. Palekha Yu.M., Svinarov A.V. (2015). Vykorystannia HIS pry hroshovii otsintsi zemel naselenykh punktiv. [The use of GIS in the monetary valuation of land settlements]. Kharkiv, Ukraine: 183.

7. Patychenko O. M. (2013). Metodolohichni pytannia strukturyzatsii ZIS ta vykorystannia spilnoi heoprostorovoi modeli ZIS i mistobudivnoi HIS v normatyvnii hroshovii otsintsi zemel naselenykh punktiv iz zastosuvanniam HIS-tekhnolohii na prykladi mist Avtonomnoi Respubliky Krym. [Methodological issues of GIS structuring and use of joint geospatial model of GIS and urban GIS in normative monetary valuation of lands of settlements 
with the use of GIS technologies on the example of cities of the Autonomous Republic of Crimea]. Series: Geography. №1, 104-113.

8. Resolution of the Cabinet of Ministers of Ukraine "On approval of the Methodology of normative monetary valuation of agricultural lands" of June 21, 2019.Available at: https://zakon.rada.gov.ua/laws/show/831-2016$\% \mathrm{D} 0 \% \mathrm{BF} \# \mathrm{Text}$

9. Resolution of the Cabinet of Ministers "On approval of the Procedure for maintaining the State Land Cadastre (Annexes 2-57 to the Procedure)" of August 11, 2021.Available at: https://zakon.rada.gov.ua/laws/show/1051\%D0\%B1-2012-\%D0\%BF\#Text

10.Law of Ukraine "On Amendments to Certain Legislative Acts of Ukraine Concerning Land Use Planning" of June 17, 2020 № 711-IX.Available at: https://zakon.rada.gov.ua/laws/show/711-20\#Text

11.Public cadastral map of Ukraine. Available at: https://map.land.gov.ua/

12.Taratula R. B. (2017). Osoblyvosti heoinformatsiinoho zabezpechennia zemelno-informatsiinoi systemy. [Features of geoinformation support of land information system]. №2, 118-123.

13.State Enterprise "Kyiv Research and Design Institute of Land Management" (2007). Tekhnichna dokumentatsiia $\mathrm{z}$ normatyvnoi hroshovoi zemel sela Lychanka, Lychanskoi silskoi rady, Kyievo-Sviatoshynskoho raionu, Kyivskoi oblasti. [Technical documentation on normative monetary lands of Lychanka village, Kyiv-Sviatoshyn Raion, Kyiv Oblast]. Kyiv, Ukraine: 27.

14.Tretwak A.M., Panchuk O. Ia., Lykhohrud M.H. (1999). Avtomatyzovana informatsiino-analitychna systema "Hroshova otsinka ta opodatkuvannia zemel v Ukraini". [Automated information and analytical system "Monetary valuation and taxation of land in Ukraine"]. Zemlevporiadnyi visnyk, №2, 2126.

15.Tretiak A., Tretiak V., Kuriltsiv R. (2021) A new paradigm of land resources management and land use. Land Management Bulletin. № 10. 16-22. 


\section{П.И. Трофименко, А.Н. Третяк, Ю.В. Безгодкова, Н.В. Трофименко,}

\section{В.И. Зацерковный}

РАЗРАБОТКА И ИСПОЛЬЗОВАНИЕ БАЗЫ ДАННЫХ ГИС ДЛЯ

ЗАДАЧ НОРМАТИВНОЙ ДЕНЕЖНОЙ ОЦЕНКИ ЗЕМЕЛЬ

\section{НАСЕЛЕННЫХ ПУНКТОВ}

Аннотация. $B$ работе представлень результаты исследований разработки базы данных ГИС для задач нормативной денежной оченки земель населенных пунктов и отражены прикладные аспекты ее использования на примере села Личанка, Дмитровской территориальной громады, Бучанского района, Киевской области.

Представлен алгоритм разработки базы данных ГИС для проведения нормативной денежной оценки земель населенного пункта. Представленный алгоритм оценки позволяет с высокой точностью проводить нормативную денежную оценку населенных пунктов, осуществлять автоматизированное обновление на определенную дату, получать необходимую информацию по запросу, проводить аналитические операции и построение специализированных оченочных картосхем.

Разработка базы ГИС предполагала выполнение двух этапов. На первом этапе формирования исходной земельно-оценочной базы в атрибутивную таблииу были занесены данные с Публичной кадастровой карты Украины о земельных участках в пределах населенного пункта по следующим позищиям: кадастровый номер земельного участка, площадь, га, форма собственности, целевое назначение и функциональное использование земельного участка, номер кадастровой зоны, в которой находится каждый земельный участок, номер земельно-оценочного района населенного пункта, величины базовой стоимости земельных участков, значение зонального коэффициента (Км2), коэффициента, характеризующего функииональное назначение земельного участка (Кф), информацию о местоположении участка (название улищы). Второй этап предусматривал расчет величины нормативной денежной оценки 
каждого из 1279 земельных участков и был выполнен за счет встроенной в среду Агс Мар функции «Калькуляцฺии числовых значений».

После завершения разработки базы данных ГИС выполнялся этап тестирования разработанной земельно-оченочной базы, который предусматривал применение разнообразных исполнений запросов, геопространственного анализа, использованием функций буферизации, топологической оверлей (сечение).

В результате проведенного анализа построены следующие картосхемь: «Влияние локальных факторов по удаленности земельного участка от центра населенного пункта», «Влияние локальных фракторов по удаленности земельного участка от магистралей», «Влияние локальных фракторов по экологической ситуацииџ, «Влияние локальныхх факторов по обеспеченности электроэнергией», «Влияние локальных факторов на удаленность от дорог с твердым покрытием», «Влияние локальных факторов на обеспеченность цุентрализованным водоснабжением», «Влияние локальных фракторов на обеспеченность цуентрализованной канализащией», «Влияние локальных факторов на обеспеченность цүентрализованным газоснабжением», «Картосхема стоимости земельных участков по результатам нормативной денежной оченки», «Картосхема установки буферных зон по величине локальных коэффициентов», «Картосхема прибрежных защзитных полос вокруг водных объектов с выделением зон их пересечения с земельньми участками».

Благодаря применению имеющихся в среде ГИС спецฺиальньхх функичий геопространственного анализа показаны примеры разработки высокоинформативных картографических материалов в виде специиальных цуенообразующчих зонировок территории населенного пункта. Показана цุелесообразность применения базы данных ГИС для задач мониторинга качественного состояния земель, соблюдения их правового режима $u$ возможности осуществления контроля выполнения фискальных обязательств владельцами земельных участков и пользователями. 
Ключевые слова: нормативная денежная оценка, база данных ГИС, геопространственный анализ, буферизация, земельно-оценочное зонирование, картосхемы.

П.І. Трофименко, А.М. Третяк, Ю.В. Безгодкова,Н.В. Трофименко, В.І. Зацерковний

РОЗРОБКА ТА ВИКОРИСТАННЯ БАЗИ ДАНИХ ГІС ДЛЯ ЗАВДАНЬ НОРМАТИВНОЇ ГРОШОВОЇ ОЦНКИ ЗЕМЕЛЬ НАСЕЛЕНИХ ПУНКТІВ

Анотація. В роботі представлено результати досліджень розробки бази даних ГІС для завдань нормативної грошової оцінки земель населених пунктів та висвітлено прикладні аспекти ї̈ використання на прикладі села Личанка, Дмитрівської територіальної громади, Бучанського району, Київської області.

Наведено алгоритм розробки бази даних ГІС для проведення нормативної грошової оцінки земель населеного пункту. Представлений алгоритм оцінки дозволяє з високою точністю проводити нормативну грошову оцінку населених пунктів, здійснювати ії автоматизоване оновлення на певну дату, отримувати необхідну інформацію за запитом, проводити аналітичні операчії та побудову спеціалізованих очіночних картосхем.

Розробка бази ГІС передбачала виконання двох етапів. На першому етапі формування вихідної земельно-оціночної бази до атрибутивної таблиці було занесено дані із Публічної кадастрової карти України про земельні ділянки в межах населеного пункту за наступними позиціями: кадастровий номер земельної ділянки, площа, га, форма власності, иільвове призначення та функиіональне використання земельної ділянки, номер кадастрової зони, в якій знаходиться кожна земельна ділянка, номер земельно-оціночного району населеного пункту, величини базової вартості земельних ділянок, значення зонального коефіиієнта (Км2), коефіиієнта, щэо характеризує функиіональне призначення земельної ділянки (Кф), інформацію про місце розтамування 
ділянки (назва вулищуі). Другий етап передбачав обрахунок величини нормативної грошової оичінки кожної з 1279 земельних ділянок та був виконаний з допомогою вбудованої в середовище Аrс Мар функції «Калькуляції числових значень».

Після завершення розробки бази даних ГІС, виконувався етап тестування розробленої земельно-очіночної бази, який передбачав застосування різноманітних виконання запитів, геопросторового аналізу, використанням функиій буферизації, топологічного оверлею (перетин).

В результаті проведеного аналізу, побудовано наступні картосхеми: «Вплив локальних факторів щуодо віддаленості земельної ділянки від центру населеного пункту», «Вплив локальних факторів щзодо віддаленості земельної ділянки від магістралей», «Вплив локальних факторів щуодо екологічної ситуацุї̈», «Вплив локальних факторів щзодо забезпеченості електроенергією», «Вплив локальних факторів щзодо віддаленості від доріг з твердим покриттям», «Вплив локальних факторів щуодо забезпеченості цүентралізованим водопостачанням», «Вплив локальних фракторів щуодо забезпеченості централізованою каналізацією», «Вплив локальних факторів щзодо забезпеченості цчентралізованим газопостачанням», «Картосхема вартості земельних ділянок за результатами нормативної громової оцінки», «Картосхема встановлення буферних зон за величиною локальних коефійієнтів», «Картосхема прибережних захисних смуг навколо водних об’єктів з виділенням зон їх перетину з земельними ділянками».

Завдяки застосуванню наявних в середовищі ГІС спеціальних фууниій геопросторового аналізу, показано приклади розробки високоінформативних картографічних матеріалів у вигляді спечіальних изіноутворюючих зонувань території населеного пункту. Показано доцільність прикладного застосування бази даних ГІС для завдань моніторингу якісного стану земель, дотримання їхнього правового режиму та можливості здійснення контролю виконання фіскальних зобов'язань власниками земельних ділянок та користувачами. 
Ключові слова: нормативна грошова оцінка, база даних ГІС, геопросторовий аналіз, буферизація, земельно-оціночне зонування, картосхеми. 